\title{
SEDIMENTOLOGY AND STRATIGRAPHY OF THE MORRISON FORMATION IN DinOSAUR NATIONAL MONUMENT
}

\author{
CHRISTINE E. TURNER $\bullet$ FRED PETERSON \\ U.S. GEOLOGICAL SURVEY $\downarrow$ DENVER, CO
}

The overall goal of this study is to establish a stratigraphic, sedimentologic, and geochronologic framework for the Upper Jurassic Morrison Formation within Dinosaur National Monument and to tie that framework to the rest of the Colorado Plateau and other important vertebrate fossil-bearing localities in the western United States. The study is also intended to complement ongoing paleontological inventories of the Morrison Formation within Dinosaur National Monument (DNM).

The project has four main objectives in order to achieve the overall goal. These include 1) document and describe the stratigraphy of the Morrison Formation in the Monument to provide a stratigraphic framework for the fossil vertebrate inventories; 2) identify depositional environments of the Morrison Formation within DNM and their evolution through time, with particular emphasis on fossil-bearing units; 3) establish a geochronologic sequence in the Morrison Formation by collecting datable materials at critical stratigraphic intervals (that is, collecting bentonite beds for isotopic dating and collecting rock types favorable for containing microfossils for paleontologic dating); 4) extend the correlations developed within DNM to other dinosaur-bearing Morrison localities in the Western Interior of the U.S. (for detailed regional relationships see Turner \& Peterson 1992).

\section{- PROJECT ACCOMPLISHMENTS TO DATE}

The research emphasis during the first year of the project (1990) was to identify the various members and other important stratigraphic units in the Morrison Formation, describing and sampling the formation at three localities in and near Dinosaur National Monument, and identifying the proper contacts of the formation. The goal of this approach was to be able to compare the members in DNM with the members or correlative beds elsewhere in the Western Interior of the U.S. and to get the samples to the various specialists early in the project so that time-consuming and labor-intensive sample preparation and analysis could begin. This was to ensure that the results would be available before the end of the project. Thus, during the first year, efforts were concentrated on two of the objectives-determining the basic stratigraphy of the Morrison Formation and sampling for geochronologic determinations (that is, sampling for the purpose of obtaining isotopic and microfossil age determinations). Our effort during the second year was devoted primarily to sedimentologic studies, especially of the quarry interval, but work was also begun on the regional studies that are necessary to place the dinosaur fauna at DNM in its context with other Late Jurassic dinosaur faunas elsewhere in the 
Western Interior of the U.S. The following discussion is a summary of our research thus far and it is organized to follow the four primary goals of the project: stratigraphy, sedimentology, geochronology, and regional relationships.

\section{STRATIGRAPHY}

Four members are now recognized in the Morrison Formation in the Monument; from oldest to youngest these are the Windy Hill, Tidwell, Salt Wash, and Brushy Basin Members. The Windy Hill Member consists predominantly of marine sandstone and is only present as far south as northern Utah and northern Colorado. It does not extend south to the central or southern parts of the Colorado Plateau although it or correlative beds do extend farther north into Wyoming, Montana, western South Dakota, and southeastern Idaho. The Tidwell Member in the DNM area consists largely of gray mudstone deposited mostly in continental environments and is quite similar to the Tidwell elsewhere on the Colorado Plateau. The Salt Wash Member consists largely of fluvial sandstone beds in the western part of DNM, as it does farther south, but locally at Deerlodge Park it consists largely of eolian sandstone. The Brushy Basin Member is divided into two parts in and near DNM; the lower part consists largely of nonswelling clays and is mostly red whereas the upper part consists largely of swelling clays and is mostly grayish-green although it also contains some red beds near the top. It was deposited in continental environments, mostly in lakes and overbank floodplains although a small but important part was deposited in stream channels.

Another important aspect of this phase of the research was to determine the proper contacts of the formation, or, to put it another way, to define just exactly what the Morrison Formation is. The lower contact presents no significant difficulties in most places. It is a regional unconformity between grayish-green mudstone in the underlying Redwater Member of the Stump Formation and light brown sandstone in the overlying Windy Hill Member of the Morrison Formation. The upper contact of the formation is not as easy to determine because similar rock types commonly are present at the top of the Brushy Basin Member and in the lower part of the overlying Cedar Mountain Formation. Additional research will be needed to clarify the nature of this contact although work already accomplished suggests that a regional unconformity is present and that the contact can be determined, at least in most cases, by an assemblage of characteristics rather than by any single feature.

Also during the first field season, detailed sections of part or all of the Morrison Formation were measured at 3 localities in or near DNM. Complete sections of the entire formation were measured about $1 \mathrm{~km}$ west of the quarry (the DQW section) and near Bill White's Cabin in Deerlodge Park (the BWC section). A partial section of the Windy Hill, Tidwell, and Salt Wash Members was also measured in Rainbow Draw (the RD section). Of these, the DQW section was sampled most intensively for isotopically datable materials and for microfossils, chiefly palynomorphs (spores and pollen), that will also help to date the formation. The Windy Hill, Tidwell, and Salt Wash Members were sampled for microfossils during the first field season (1990) and the Brushy Basin Member was sampled intensively during the second field season (1991) in company with our palynologist, Ron Litwin, in order to apply his skills in obtaining rock types most suitable for yielding palynomorphs.

The BWC section was sampled mostly for isotopically datable materials, and the RD section was not sampled intensively although several likely palynomorph-bearing beds were found and sampled and an important bentonite sample for isotopic dating was collected from low in the Tidwell Member. Because all the other samples for isotopic dating came from the Brushy Basin Member, the sample from the Tidwell Member is especially important for helping us determine the span of time represented by the entire formation.

In sampling for microfossils, it has been found that red beds almost never yield palynomorphs because the oxidation that produces the red color also destroys palynomorphs. Thus, the lower part of the Brushy Basin Member, which consists largely of red beds, is not a likely candidate for containing these fossils. However, a locality was found at the Rattlesnake Mine about $\mathbf{4 0} \mathrm{km}$ southeast of Moab, Utah, that has a thin channel filled with carbonbearing mudstone, an ideal rock type for containing palynomorphs. This was sampled during the second (1991) field season in hopes that microfossils from it will accurately date this important part of the formation. 
Charophytes are scarce at DNM and therefore are of minimal value for detailed dating of the formation there. (Charophytes are lacustrine algae; technically, the most useful fossilized part of these plants is called the gyrogonite, which is the calcified sheath surrounding the female reproductive parts.) They are locally abundant in a limestone and underlying mudstone pair of beds in the Brushy Basin Member about $5 \mathrm{~m}$ below the quarry interval near the DQW section, and they have been reported to be in a thin mudstone lens in the quarry sandstone bed in the quarry building. Both of these localities have been sampled but even if they yield age-diagnostic charophytes, they will only date a small part of the formation at DNM although that will help in relating the DNM section to the regional stratigraphic framework. On the other hand, charophytes are considerably more abundant throughout a greater thickness of the formation farther east in central Colorado and eastern Wyoming where they should prove highly useful for detailed dating purposes.

Dinoflagellates are another type of palynomorph that is sometimes found in marine rocks and, if found, may prove helpful for precise dating of the Windy Hill Member. They are also green algae but smaller and about the same size as spores and pollen--too small to be seen with the naked eye--and are responsible for the "red tides" sometimes seen in open marine waters and marine embayments in modern settings. Samples collected from the Redwater Member of the Stump Formation and the Windy Hill Member of the Morrison will be analyzed for these microfossils as well as spores and pollen, in hopes of obtaining additional information on the age of these stratigraphic units.

Although most of the effort of the first (1990) field season was concentrated on stratigraphic studies and geochronologic studies aimed at sampling for datable materials, most of the effort of the second (1991) field season was concentrated on the other two objectives of the project, that is, on the detailed sedimentology and regional relationships.

\section{SEDIMENTOLOGY}

During the second (1991) field season, considerable effort was devoted to studying the detailed sedimentology of the quarry interval (objective 2) so that a better understanding could be obtained of the conditions under which the abundant bones in the quarry bed were deposited. We use the term quarry interval to refer to the entire sandstoneconglomerate assemblage of beds, about 7-10 m thick, that extends along the outcrop belt from the quarry building east for about $1,000 \mathrm{~m}$ to the vicinity of the draw just east of Swelter Shelter. This interval contains approximately a dozen vertically and laterally appressed individual fluvial sandstone beds of which only one is the quarry bed that contains the abundant bones.

The chief sedimentologic methodology employed was lateral profiling in which important rock types and bedding surfaces in closely spaced measured sections through the quarry interval are traced and correlated laterally along the outcrop from section to section. In all, we measured about 32 sections along approximately $1,000 \mathrm{~m}$ of outcrop, giving an average spacing of about $30 \mathrm{~m}$ between sections. In addition, the measurements needed to construct a map of the quarry interval along the outcrop east of the quarry building were also obtained. Several hundred paleocurrent measurements were made in the various beds within the quarry interval so that the direction of flow of the ancient streams that deposited the interval could be determined. We also made paleocurrent measurements of the fluvial sandstone beds above the quarry interval to determine the flow of streams after deposition of the quarry interval (no fluvial sandstone beds were found just below the quarry interval). All in all, we made approximately 730 paleocurrent measurements. The measurements clearly show that most of the streams flowed southeastward. We also made measurements of about 130 pelecypod valves to document their orientation with respect to the stream currents.

A map was constructed and the measured sections, lateral profiles, and paleocurrent measurements were placed in their original positions after mathematically rotating the steeply inclined beds to their originally horizontal position. With this, we will be able to make other measurements or interpretations such as determining the approximate width of the stream channels, their sinuosity, and maximum depths.

Within the quarry building we identified 3 separate vertically stacked fluvial beds in the quarry interval. The lower bed only contains scarce disarticulated bones and bone fragments. The middle 
bed is the quarry bed and contains the abundant disarticulated bones, articulated bone segments, and the fairly compact but large assemblages of bones, each assemblage almost certainly belonging to an individual animal. The upper bed contains some isolated bones and several articulated bone segments but it contains far fewer bones than the middle bed.

The southern edge of the quarry bed was identified in the southwest corner of the exposure in the quarry building but, because the upper part of the quarry bed was eroded during deposition of the overlying bed, only the lower part is still preserved. Paleocurrent studies indicate that the original trend of the stream that deposited the quarry bed within the building was about east-southeast. The geometric relationships of the channel edge, the trend of the quarry bed, and the orientation of the building indicate that extending the quarrying operation downdip in the middle of the building where the upper bed has not yet been removed probably will not result in the discovery of any significant quantity of bones.

The quarry bed is unique in that it is the only fluvial bed in the quarry interval that is present at two places along the outcrop trend. Most of the streams that deposited the quarry interval flowed southeastward and therefore passed across the area of the present east-west-trending outcrop belt only once. In contrast, the stream that deposited the quarry bed flowed almost due east (actually east-southeast) at the site of the quarry building and then turned southeastward, intersecting the outcrop belt again several hundred meters east of the building. The lateral continuation of the quarry bed was identified with a fairly high degree of certainty in the outcrops east of the quarry building where the bed contains numerous disarticulated bones and several segments of articulated vertebrae. There, the quarry bed extends from the first gully east of the parking lot to a point several hundred yards east of the second gully east of the parking lot. Should future management plans make it desirable to obtain more bones in large quantities, this locality would be the best place to begin new quarrying operations.

The research accomplished in the second field season (1991) indicated the need for a major reinterpretation of the origin of the quarry bed. Previously, the quarry bed had been interpreted as a side bar or possibly a point bar on the edge of a stream and it had been suggested that the bones and dinosaur carcasses washed up on this bar and were subsequently buried. Instead, the evidence indicates that most of the bones were deposited in the deeper part of a stream channel and relatively few bones were deposited near the stream banks. This interpretation was obtained largely by doing the lateral profiling throughout the entire quarry interval that allows one to identify the different parts of the stream channel and applying those findings to the beds within the quarry building. Thus, new approaches to fluvial sedimentology that were developed mostly during the last decade made it possible to improve on the previous interpretation that had been with us for about 70 years.

\section{GEOCHRONOLOGY}

Geochronology includes both paleontologic (or relative) and isotopic (also called radiometric or absolute) dating methods. One of the goals of geochronologists is to calibrate the standard geologic time scale, which is based on paleontologic dating methods, with isotopic dates so as to put numbers for millions of years before the present on the subdivisions of geologic time. For example, the Late Jurassic Epoch is divided into three Ages as shown below along with the currently accepted best estimates for the age of their boundaries in millions of years before the present (Ma). One of our goals is to place the Morrison Formation within this time framework using isotopic and paleontologic methodologies.

$$
\begin{gathered}
\text { A Late Jurassic Time Scale } \\
\text {--141.1 Ma---- } \\
\text { Titkonian Age } \\
\text { Kimmeridgian Age } \\
\text {--152.1 Ma-7 Ma--- } \\
\text { Oxfordian Age } \\
--157.1 \text { Ma--- }
\end{gathered}
$$

For micropaleontologic age determinations, we collected numerous samples for palynomorphs and charophytes. These either have been or are being processed in the appropriate laboratories and, hopefully, identifications and age determinations from the samples that yielded the microfossils will be done in the near future. One sample from the upper part of the Brushy Basin Member near Montezuma Creek in southeastern Utah that was run by our 
palynologist, Ron Litwin, gave a Tithonian age. A search through the literature showed that almost all of the charophytes that have been recovered by previous workers came from the lower half of the formation from beds that correlate with the Tidwell and Salt Wash Members and the lower part of the Brushy Basin Member. An evaluation of those Morrison species that also occur in the Upper Jurassic rocks of the northwest German basin where their relative age ranges have been carefully determined suggests a Kimmeridgian age. This conclusion must be considered tentative, however, because the identifications of the Morrison charophytes were published $\mathbf{3 0}$ or more years ago and may be in need of revision by now. Fortunately, we have a specialist from the Freie Universitat in Berlin, Germany, (Michael E. Schudack) working on charophytes collected during the course of this study and he should be able to give us much firmer identifications and age determinations in the near future.

For isotopic dating we rely almost exclusively on the single-crystal laser-fusion ${ }^{40} \mathrm{Ar} /{ }^{39} \mathrm{Ar}$ method of isotopic dating in which crystals of datable minerals (usually sanidine, a type of potassium feldspar) are separated from bentonite beds, dated individually, and the results averaged to give a final date. (Bentonite is a type of swelling clay that is the alteration product of volcanic ash. Thus, dating the minerals in a bentonite bed actually dates the time of eruption of the volcano when the datable mineral grains cooled and became closed systems. To put it another way, the eruption is when the radiometric "clock" begins "ticking".)

\section{LITERATURE DATA SYNTHESIS}

A study was made of the published literature and of unpublished materials, made available to us by several workers, in order to gain an understanding of the age of the Morrison Formation as well as it can be determined at this stage of the study. The materials were evaluated in light of our most recent understanding of the stratigraphy of the Morrison Formation and its relationship to underlying and overlying rocks. The study was undertaken to guide our research on the microfossil biostratigraphy of the formation. The literature search, augmented by our field research, demonstrates that the formation is Late Jurassic in age and almost certainly is not partly Early Cretaceous in age, as had been thought by some workers. In those cases where we have been able to make a field or literature check or where we have more reliable data, reports of an early Cretaceous age for part of the Morrison are the result of either misidentification of the upper contact of the formation or of inaccurate dating techniques.

These and other studies suggested that the lower part of the Brushy Basin Member might give us the greatest problem in our attempts to obtain detailed dates throughout the Morrison Formation, which would have been unfortunate because the available data suggests that an important timestratigraphic boundary (the boundary between the Kimmeridgian and Tithonian Stages) is within or near this unit. Good dating of this part of the formation is especially important because so many of the dinosaur remains in the western U.S. are in the Brushy Basin Member. The lower part of the member consists largely of red mudstone, which is a poor rock type for the recovery of palynomorphs because the oxidation process that produces the red color also destroys palynomorphs. This part of the member also lacks lacustrine beds in most localities so it does not seem a likely candidate to contain charophytes. Fortunately, we found localities where either palynomorphs or charophytes occur in this part of the member. We found one locality about $50 \mathrm{~km}$ south-southeast of Moab, Utah, where a small channel in the lower part of the Brushy Basin Member is filled with carbon-bearing mudstone--an ideal rock type for containing palynomorphs. The mudstones at this locality were therefore sampled in detail in hopes that a precise age determination can be obtained that will fill the gap in age determinations for this part of the formation. We were also fortunate in discovering a locality in Garden Park where charophytes occur in such abundance that they are easily found in hand samples with a hand lens. These occur in lacustrine strata in beds that correlate with the lower part of the Brushy Basin Member. Thus, if these samples yield age-diagnostic microfossils, we will have dated a critical part of the formation.

\section{- LiteratURE CITED}

Averett, M. E. 1991. Discovering an Iguanodon: In: W. R. Averett (ed.). Dinosaur quarries and tracksites tour, western Colorado and eastern Utah: Grand Junction Geological 
Society, Guidebook p. 49.

Armstrong, H. J. and E. S. McReynolds. 1987. Paleontological significance of the dinosaur triangle; In: W. R. Averett (ed.). Paleontology and geology of the dinosaur triangle: Grand Junction Geological Society and Museum of Western Colorado, Guidebook, p. 1-4.

Bralower, T. J., K. R. Ludwig, J. D. Obradovich and D. L. Jones. 1990. Berriasian (Early Cretaceous) radiometric ages from the Grindstone Creek section, Sacramento Valley, California: Earth and Planetary Science Letters, v. 98, no. 1, p. 62-73.

Harland, W. B., R. L. Armstrong, A. V. Cox L. E. Craig, A. G. Smith and D. G. Smith. 1990. A geologic time scale 1989: Cambridge University Press, New York, $263 \mathrm{p}$.

Holt, E. L. 1940. The Morrison and Summerville Formations of the Grand River Valley and their vertebrate and invertebrate fauna: Unpublished Master's thesis, University of Colorado, Boulder, $71 \mathrm{p}$.

Imlay, R. W. 1982. Jurassic (Oxfordian and Late Callovian) ammonites from the Western Interior region of the United States: U.S. Geological Survey Professional Paper 1232, $44 \mathrm{pp}$.
Turner, C. E. and F. Peterson. 1992. Sedimentology and stratigraphy of the Morrison Formation in Dinosaur National Monument, Utah and Colorado. Semiannual Report. NPS Rocky Mtn. Region, Denver, CO $36 \mathrm{pp}$.

Waagè, K. M. 1955. Dakota Group in northern Front Range foothills, Colorado: U.S. Geological Survey Professional Paper 274-B, $51 \mathrm{pp}$.

Waagè, K. M. 1959. Stratigraphy of the Dakota Group along the northern Front Range foothills, Colorado: U.S. Geological Survey Oil and Gas Investigations Chart OC-60.

Waldschmidt, W. A. and L. W. LeRoy. 1944. Reconsideration of the Morrison Formation in the type area, Jefferson County, Colorado: Geological Society of America Bulletin, v. 55, no. 9, p. 1097-1114. 